\title{
Impact of Leadership Style and Demographic Profile on Accounting Student Performance - The Case of Academic Administrators and Faculty Members in the Philippines
}

\author{
John Christian Cha*, James Thadeo Calleja, Patrick Giorgio Mendoza, \\ Jose Luis Yupangco and Rodiel C. Ferrer
}

\begin{abstract}
Manuscript type: Research paper

Research aims: This study aims to investigate how leadership styles and the demographic profiles of academic administrators and faculty members can influence the university students' performance in the Board Licensure Examination for Certified Public Accountants (BLECPA).

Design/Methodology/Approach: The leadership styles of the academic administrators and faculty members are measured through the
\end{abstract}

\footnotetext{
* Corresponding author: John Christian Cha is currently working as a freelance accounting consultant. He is a certified public accountant and a holder of Bachelor's Degree on Accountancy and Applied Economics from Ramon V. Del Rosario College of Business and School of Economics of De La Salle University, 2401 Taft Avenue, Manila 1004 Philippines. Email: john_christian_cha@dlsu.edu.ph

James Thadeo Calleja is a Certified Public Accountant at the PricewaterhouseCoopers (PwC) Philippines and a holder of an undergraduate degree in Accountancy at De La Salle University, 2401 Taft Avenue, Manila 1004 Philippines. Email: james_calleja@dlsu.edu.ph

Patrick Giorgio Mendoza is a certified public accountant and a holder of an undergraduate degree in Accountancy at De La Salle University, 2401 Taft Avenue, Manila 1004 Philippines. Email:patrick_giorgio_mendoza@dlsu.edu.ph

Jose Luis Yupangco is currently in the tax practice of PricewaterhouseCoopers (PwC) Philippines. He is currently a doctoral scholar of jurisprudence at the De La Salle University, Manila 1004 Philippines. Email:jose_luis_yupangco@dlsu.edu.ph

Rodiel C. Ferrer is a Professor in the Department of Accountancy, De La Salle University, Manila 1004 Philippines. Email: rodiel.ferrer@dlsu.edu.ph
}

https://doi.org/10.22452/ajba.vol12no2.7 
Bass model. Data are collected from 94 academic administrators and faculty members attached to 35 top performing colleges/universities in the 2017's BLECPA.

Research findings: The results suggest that the leadership styles and the demographic profiles of the academic administrators affect the students' performance in the BLECPA.

Theoretical contribution/Originality: This study extends on the existing literature by providing empirical evidence which highlight the relationship between academic leadership styles and universities' performance in the BLECPA. This outcome focusses on universities in and outside of Manila. This study uses a more sophisticated estimation technique to address the limitations of the classical linear regression model (CLRM). Moreover, this study evaluates leadership by incorporating both the administrators and the faculty members' leadership styles. In that regard, this study differs from existing studies which had focused on a single source of leadership.

Practitioner/Policy implications: The findings of this study inform universities on how leadership style and the characteristics of academic administrators, and faculty members may influence universities' performance. Policies can be formulated based on the findings of this paper, particularly those offering accountancy education for both the Philippines and the ASEAN region.

Research limitation: This study does not take into account the differences of the organisational structure and the number of staff and students of the universities.

Keywords: Bass Leadership Model, Demographic Profile, Student Performance, Higher Institution Education

JEL Classification: M49

\section{Introduction}

Despite the fact that the board licensure examination for certified public accountants (BLECPA) had "not conceptually changed for over 40 years" (Tan-Torres, 2017), the national passing rate over the past few decades seemed to show no improvement. This is amidst an era of more schools offering the Bachelor of Science in Accountancy (BSA) program ${ }^{1}$ when compared to its first conceptualisation (Jeffrey, 2015). However, it has been well documented by the Professional Regulatory Commission

\footnotetext{
${ }^{1}$ Only 300 schools offered BSA during the first inception of the BLECPA in 1927. Today, the number of schools offering BSA is near 500 (PRC, 2017).
} 
(PRC), that certain schools had remained consistent in terms of having reputable performances in the said board exams. With these top performing schools serving as benchmarks, many initiatives, both at the school and national level, have been made to increase the quality of the accountancy education in the Philippines. The end goal is to increase the number of qualified accounting practitioners in the region. Nevertheless, such initiatives have been slow to take effect in the Philippines. A report by the Philippines Regulation Commission (PRC) stated that the passing rate of the BLECPA had dropped, and had been inconsistent from the year 2011-2017 (Professional Regulatory Commission, 2017) (Appendix 1). When compared with top performing universities globally, the performance of the local universities seemed significantly lower. This phenomenon appears to be an acute problem for the Philippines. The poor performance of the graduates in ten CPA Board examinations for five consecutive years could lead to the gradual phase-out and closure of the accountancy programmes. Given this situation, universities in the Philippines offering the accountancy programmes need to closely monitor the performance of their BSA graduates in the BLECPA.

Various initiatives have been initiated by the universities, professional organisations and national government agencies to improve the quality of the accountancy programmes in the Philippines. One good example is the "modular" programme offered by the De La Salle University. This is reminiscent of a "school-led innovation" which is characterised by two weeks' intensive subject modules. Another example is the restructuring of the BLECPA curriculum by the Board of Accountancy (BOA), moving from seven subjects to six so as to match the board examinations' curriculum requirements as published by the Commission on Higher Education (CHED). Recently, the Supreme Court in Antiola vs. UST ${ }^{2}$ had held that faculty members at the tertiary level should possess, or be in the process of attaining, at least a master's degree while academic administrators need to be holders of a doctoral degree (Tan-Torres, 2017). This imposition is another initiative of the government to upgrade the quality of the teaching and administrative staff of tertiary institutions.

A study by Oxford Economics (2012) found that tomorrow's demand for global skills would be substantially different from those of today, and this means that countries throughout the world need

${ }^{2}$ G.R. No. 211273 dated 18 April 2018. 
to adapt to the environmental changes quickly in order to sustain the employability of their country's graduates. Without doubt, these global changes will influence the required skills of business professionals, including professional accountants. According to the World Bank, improving the quality of education is the most important for sustaining development in the ASEAN region (World Bank Group, 2014), among which, the Philippines has the highest minimum number of units to obtain in order to be awarded an accounting degree. Despite the stringent requirements, there is still a current shortage of certified accountants in the country. Former Professional Regulation Centre (PRC) chief Leonor Rosero attributed this phenomenon to the declining quality of higher education due to sub-par academic institutions in the Philippines. Nonetheless, she proposed that this be improved through the efforts of school administrators by enhancing the quality of their programmes (Santos, 2008).

Directing, motivating and leading academic institutions to success is a heavy responsibility, thus it relies on the quality of the academic leadership. Leadership is an enigmatic concept to study because it is difficult to understand how one leader is different from another and can take an institution to success while another fails to do so. Literature (Koh, Steers, \& Terborg, 1995; Sirisookslip, Ariratana, \& Tang, 2015; Okoji, 2015) has, to some extent, provided some directions on this, showing how the inherent qualities (i.e. demographic profile) of academic leaders may be able to bring universities to success. This is accomplished when the leader is able to motivate both the faculty members and the students towards successfully performing their tasks, which are measured against a pre-set of established standards. The decisions made by such academic leaders are relevant to many aspects of their universities' operations. Needless to say, these decisions are vital to the universities' success. Of course, sound decisions are mostly based on logic, experience and information, but what many people do not know is that these decisions are also inherently motivated by the individual's characteristics (Jones \& Bekhet, 2015; Bell, Rvanniekerk, \& Nel, 2015).

Consequently, it is important to investigate how these individual qualities (i.e. "demographics") can be translated into the different leadership styles, as defined by McGregor (1960). The results obtained from our study were then qualified with those of past studies so as to uncover these inherent leadership characteristics, and to see how these can be translated into academic success, which is measured by the students' performance. Correspondingly, our study also attempts to 
make three significant contributions to the body of literature related to academic leadership and school performance.

First, most studies (e.g. Day, Gu, \& Sammons, 2016; Huguet, 2017) had focussed on the leadership behaviours of individuals who hold certain posts, such as principals, heads of department, programme coordinators and deans. This tendency was based on the belief that such individuals were the primary source of leadership direction in educational institutions. Yet, scholars such as Kythreotis, Pashiardis and Kyriakides (2010), and Balwant, Birdi, Stephan and Topakas (2018) argued that the academics who served as course instructors could also influence an educational institution's direction, goals and effectiveness. It was highlighted that in the education setting, individuals who could be described as leaders, were not confined to those who held positions such as principals, curriculum developers, school administrators and others. Individual teachers, instructors or lecturers can also influence students by guiding, structuring, and facilitating activities and relationships. They can lead students through mentoring, coaching or supervising them on research projects, classroom activities, assignments and others. Although this has been highlighted, little has been done to examine the effects of faculty members' leadership styles on the classroom. In our study, we investigate the leadership behaviours by incorporating the perception of the administrators (e.g. head of department, programme coordinators and deans) and the faculty members (lecturers). This is based on the assumption that a class of students is a small organisation that may be studied, and managed by following the organisational and manage-ment theories.

Second, this study also incorporates a novelty concept by including a control variable that was not included in previous studies (Abenes, Corpus, \& Oblea, 2017). We extend the sample size by surveying schools not only within Metro Manila, but also those outside Manila. The data would thus allow us to incorporate a new control variable, i.e. the differences in location.

Third, this study makes use of the state-of-the-art estimation technique to control for possible errors when using more primitive models. The linear regression model (CLRM) was used in the Abenes et al. (2017) study which clearly presented some problems with inferences. Gujarati and Porter (2009) had mentioned that one of the CLRM assumptions require the dependent variable to be continuous. In our study, a more sophisticated estimation technique was introduced to control for the potential violation of the CLRM assumptions. 
The remainder of this paper is organised into five sections. Section 2 presents the literature review, Section 3 discusses the conceptual framework developed, Section 4 describes the methodology employed, Section 5 discusses the empirical findings and Section 6 brings the paper to conclusion.

\section{Literature Review and Hypotheses Development}

\subsection{Leadership}

Leadership and its concept of empowerment towards those who are being governed is a strong factor that determines the performance of an individual. Review of evidence (Leithwood, Louis, Anderson, \& Wahlstrom, 2004) suggests that successful leadership can play a highly significant role. Yet, its role in improving students' learning and performance is often underestimated. Leadership is not just about the ability to empower an individual to succeed in a certain task, but also the ability to continuously provide guidance and improvement for other individuals. With that, many questions arise with regards to the right leadership which ought to be implemented within institutions.

Universities, as organisations, need to be managed like all other organisations (Van Deventer, 2007) because universities have specific work to perform. These work, henceforth, duties and responsibilities, are allocated to respective individuals so as to fulfil the universities' specific organisational aims. Such organisational aims are the creation of a culture of lifelong learning and teaching where improved learner performance becomes a result (Ndlovu, 2009). Within the educational system or setting, Ndlovu (2009) had investigated the impact of management on learners' performance, using schools in Nongoma, as a case study. The three schools that were selected in the case study represented the best performing school, the average performing school and the worst performing school for Grade 12, for three consecutive years. The study concluded that management behaviours do affect learners' performance. This is because the highest level of performers are managed with appropriate management and leadership style. The findings further revealed that a school cannot operate in isolation; it needs the support of other stakeholders and outside assistance.

Yahya (2015) found that leadership styles played an important factor in improving the academic performance of students. It appears that the principal's leadership style, gender, educational qualification 
and experiences had a contributing influence on the school's performance as well as the students' academic achievements. The study posited that an empowering environment is key to creating a more efficient and effective learning environment for students. Karadağ, Bektaş, Çoğaltay and Yalçin (2015) utilised the random effects model to analyse the relationship between academic leadership and student performance among 28,964 subjects. They observed that leadership had an ambiguous effect on the students' performance whereas the distributive and transformational leadership style had the most substantial effect. Robinson, Lloyd and Rowe (2008) noted that academic leadership indeed impacted on student outcome. Specifically, they found that instructional leadership had three to four times larger impact, relative to transformational leadership.

In the Philippines setting, Abenes et al. (2017) designed a study which examined how the various qualities of the academic administrators affected faculty effectiveness in Metro Manila. It was observed that the administrator's age, location, tenure and academic accomplishment had an effect on faculty effectiveness. This was quantified through student satisfaction surveys. A review of the literature further showed that besides Abenes et al. (2017), there has been a lack of studies investigating the effect of leadership style of school administrators on academic performance within the Philippines. Abenes et. al. (2017) had focussed on how academic leadership affected faculty effectiveness by using student satisfaction survey but despite their findings, the outcome was not comprehensive since student satisfaction do not reflect how well the students performed. In supporting this view, some scholars highlighted that it is difficult to attach student satisfaction with educational outcome since satisfaction is a reflection of the students' perception on their educational experiences, further fuelled by feelings, emotions and subjective attitudes (Summers, Waigandt, \& Whittaker, 2005; Baron \& Corbin, 2012).

\subsection{Demographic Profile}

Bell et al. (2015) argued that due to the emergence of a younger and highly educated workforce, a leader who can deeply connect with them is a necessity. Three demographic profile variables were proposed: gender, age and education. This is because these have been found to have a significant correlation with the leadership effectiveness of local government managers. Focussing on the impact of gender on leadership 
style, Saeed et al. (2013) contested that male leaders were more flexible in solving organisational problems and desires while female leaders tended to follow procedures in accomplishing their tasks. The influence of gender on leadership styles was attributed to the individuals' inborn leader qualities (Amin \& Kamal, 2016).

In a much earlier study, Eagly and Carli (2003) provided empirical evidence to support the relationship between gender and leadership styles. They asserted that female leaders tended to use more transformational leadership; they tie employees' performance to rewards. Thus, it was deduced that this was because the female characteristics tended to be more nurturing and sensitive to others' feelings, as compared with male characteristics. In another study, Wong, Cummings and Ducharme (2013) indicated age as a factor contributing to the different leadership stance. They argued that older employees had different leadership styles as they had worked in different workplace environments. Younger leaders, in comparison, had different practices since they tended to be more energetic and likely to explore new things. Similarly, Oshagbemi and Ocholi (2013) reported that younger leaders were more comfortable in a fast-changing environment; they were more willing to take risks and they like to consider new approaches. Younger leaders were also found to have more energy and the capacity to stimulate and inspire others; they often seek out new opportunities and they tended to work vigorously in developing and promoting themselves. These attributes have been found to transform organisations as a result of the different leadership styles when compared to the older leaders. The role of educational background on leadership styles have also been documented in a few studies (Thu, Pillay, \& Mergler, 2017; Barbuto \& Burbach, 2006; Sawati, Anwar, \& Majoka, 2013). It appears that the leaders' educational background affects their ability in dealing, communicating and tolerating their employees. Managers with higher educational degrees are often more competent; they are also more inclined to practice the transformational leadership styles (Thu et al., 2017).

\subsection{Bass Leadership Model}

To understand the role of leadership styles on performance, this study employed the Bass leadership model. It has the ability to use the full range of leadership behaviours to separate the effective leaders from the ineffective leaders (Barbuto \& Burbach, 2006). Bass' full range of leadership model explores the different types of leadership which are 
presented through the use of the Multifactor Leadership Questionnaire (MLQ). It distinctly separates the leadership traits into three styles namely, transformational, transactional and laissez-faire leadership. The different leadership style focusses differently on how functional power grows and is balanced (Bass, 1990).

\subsubsection{Transformational, Transactional and Lasseiz-faire Leadership}

Transformational leadership theory suggests that leaders inspire not just their members but also the whole organisation, to work their best for the benefit of the organisation and its goals. This type of leader asks the members to go beyond their goals, from self-interest to the interest of the organisation while also challenging them to go beyond what is expected of them, and to exhibit professionalism, creativity and high moral standards (Dyck \& Neubert, 2009). Bass (1985) extended on the leader's influence towards its members. He mentioned that trust and honesty are the main traits that members look for in a leader. Members tend to follow a leader who motivates them and vastly improves their performance as well as their relationship.

Transactional leadership, on the other hand, focusses on the basic management process of controlling, organising and short-term planning. Transactional leadership is more concerned about the maintenance of the normal flow of operations. Transactional leadership is based on the idea that employees will perform based on the amount of reward they will receive. If there is non-performance of the task, a punishment will follow. The exchange between leaders and their followers takes place to achieve routine performance goals. Transactional leadership has its underpinnings on the role of supervision, organisation and group performance, and the exchanges between leaders and their subordinates. The leader's primary role is to create structures to portray what is expected from their subordinates and the repercussions of achieving or not achieving such.

The laissez-faire leadership refers to a leadership style that allows people to work on their own. Under this leadership, the leaders usually avoid making decisions, and may give teams the complete freedom to perform their tasks and to set their own deadlines (Asrar-Ul-haq \& Kuchinke, 2016). Thus, the laissez-faire leadership is considered as a passive leadership style, recognised as the least effective leadership style, and rarely supported by subordinates or followers in the organisations (Avolio \& Bass, 2004). 


\section{Research Framework and Hypotheses Development}

Based on the literature review, this study developed a conceptual framework with the formulated hypotheses indicated in Figure 1.

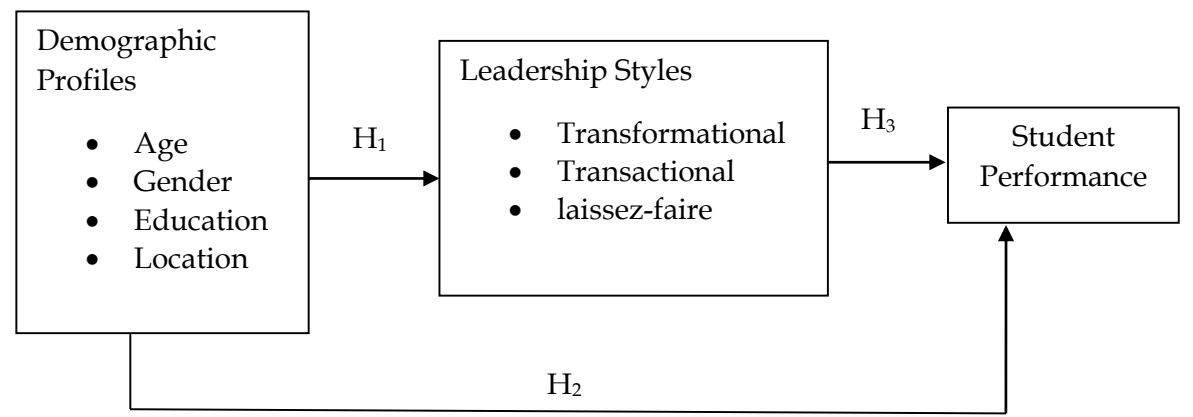

Figure 1: Research Framework

Various studies (Saeed et al., 2013; Wong et al. 2013; Thu et al., 2017) have documented the impact of the demographic profiles of leaders, both in terms of leadership styles and performance outcomes. Women, for example, have noted to demonstrate a passive avoidant leadership or the laissez-faire leadership. In some cases, they have also been recognised and identified as leaders who worked collaboratively with their followers and subordinates. Within the context of the academic environment, it was found that older teachers tended to use conventional methods of teaching; they were ill-prepared to implement new curriculum, and this affected student performance (Ahumada, 2016).

In Vietnam, Thu et al. (2017) found that educational leaders with postgraduate degrees (Master and Doctorate) tend to exhibit transformational leadership. This is possibly because many of these leaders were also trained in developed countries where transformational leadership is commonly practiced. This finding indirectly highlights that the training location may also have an influential impact on leadership style. In a much earlier study, MacNeil, Prater and Busch (2009) indicated that schools in the developed countries tended to have open climates, where students and faculty members or course instructors were comfortable in expressing ideas and suggestions. This may also be interpreted as an open environment which encourages a better leadership style. Based on these arguments, it is hypothesised that: 
$\mathrm{H}_{1}$ : The leadership styles can be explained by the demographic profiles of the academic leaders, in terms of age, gender, education and location.

$\mathrm{H}_{2}$ : The universities' performance of the BLECPA can be explained by the demographic profiles of the academic leaders in terms of age, gender, education and location.

A number of existing literature (Bronkhorst, Steijn, \& Vermeeren, 2015; Newland, Newton, Podlog, Legg, \& Tanner, 2015; Kim \& Yoon, 2015) support that different leadership styles lead to different outcomes. Among these, transformational leaders have been found to positively influence employees' self-efficacy, motivation and creativity, which in turn lead to improved firm performance (Bronkhorst et al., 2015, Newland et al., 2015, Kim \& Yoon, 2015). In contrast, transactional leaders helped to instil job satisfaction among the employees through the reward system (Epitropaki \& Martin, 2013; LePine, Zhang, Crawford, \& Rich, 2016). Although many scholars associate the laissezfaire leadership with negative outcomes (Bass \& Avolio, 1994; Judge \& Piccolo, 2004), some empirical works (e.g. Ryan \& Tipu, 2013) showed otherwise. These studies considered the laissez-faire leadership style as one that promotes self-control, empowerment and innovation. In this regard, it was interpreted as one showing respect and trust to members so as to facilitate employees' development. Within the context of the academic setting, it is expected that different leadership styles would promote different student performance rates. For instance, a faculty member/course instructor who encourages critical thinking strategies may encourage the development of creative thinking. In comparison, a faculty member/course instructor who builds trust provides students with the opportunity to try something new. Based on these arguments, it is hypothesised that:

$\mathrm{H}_{3}$ : The universities' performance of the BLECPA can be explained by the leadership styles of the academic leaders.

\section{Methodology}

A quantitative survey was engaged to collect the primary data (Appendix 2). We used the Multifactor Leadership Questionnaire (MLQ) which was developed by Bass and Avolio (1994), to evaluate the leadership style of the academic leaders and to subsequently categorise them as: (1) Transformational, (2) Transactional, or (3) Laissez-faire. The 
questionnaire contains 45 items and responses are based on the 5-point behavioural scale ( 1 - Not at all, 2 - Once in a while, 3 - Sometimes, 4 - Fairly often, and 5 - Always). This instrument has been widely used and is highly reliable and well validated. The Cronbach's $\alpha$ for the MLQ was reported to be 0.96 (Avolio \& Bass, 2004) and the instrument had also been implemented within the area of leadership practices in various contextual settings (e.g. Thu et al., 2017; Asrar Ul-Haq \& Kuchinke, 2016). In this regard, the instrument is considered as effective. The MLQ is a self-reported questionnaire. To proxy for the students' performance, we used the performance of the responding schools in the BLECPA for the period 2012-2016. Data were then collected from two different sources. This helped to reduce the problem of common method bias (Podsakoff, MacKenzie, Lee, \& Podsakoff, 2003).

The target population for this study comprised academic administrators and faculty members from the top 50 higher educational institutions located in Luzon Island. These institutions offer the accountancy programme, as ranked by the PRC. We focused on Luzon Island because it represents the largest and the most populous island in the Philippines; it is also the centre of the country's economic and political interactions, where the capital city of Manila is also located.

Prior to data collection, an invitation letter was sent to the management of the institutions to seek permission to conduct the study. Of the 35 universities approached, only 19 responded positively. Following this, we then identified the academic administrators and the faculty members involved in the accountancy programmes. The academic administrators were represented by the Deans, Deputy Deans, department heads, managers and directors of the schools whereas the faculty members were confined to those teaching the accountancy courses. The estimated sampling size at the time of study was 100, hence a total of 100 questionnaires and cover letters were despatched to the samples through the human resource manager of the participating universities. They were all given one week to complete the questionnaire. The returns only comprised 94 usable questionnaires which comprised 31 academic administrators, and 63 faculty members. Majority were males with a Master's in Business Administration (MBA) qualification and only 27 per cent of them have doctoral degrees. Table 1 illustrates.

The data in this study conforms with the CHED Memorandum Order No. 2 Series of 2011 which states that college professors must at least have a Master's degree, and administrators must be a doctorate 
Table 1: Demographic Profiles

\begin{tabular}{lcc}
\hline Demographics & Frequency & Percentage (\%) \\
\hline Designation & 31 & 33 \\
Academic Administrators & 63 & 67 \\
Faculty Members & & \\
Gender & 38 & 40 \\
Females & 56 & 60 \\
Males & & 27 \\
Academic Background & 25 & 58 \\
Doctoral Degree & 55 & 15 \\
Master in Business Administration & 14 & \\
Undergraduate Degree & & 53 \\
Location & 50 & 47 \\
Outside Metro Manila & 44 & \\
Metro Manila & & 76 \\
Age & 69 & 24 \\
Below 40 years old & 25 & \\
40 years old and above & & \\
\hline
\end{tabular}

degree holder (Commission on Higher Education, 2011) This information is also consistent with the Supreme Court's Ruling (SC) which had implemented that all college professors should have a minimum of a master's degrees Antiola vs. UST ${ }^{3}$.

The ages of the administrators followed a normal distribution which is concentrated on 40 years as the mean and this seemed to resonate with what Bonetta (2011) had said, the average time for a faculty member to become an academic head would be around 10 years. From the perspective of the faculty, it appears that many of the faculty members are either young (in their twenties) or old (in their sixties). This outcome is also consistent with what had been observed by the former chairman of the Philippines Statistics Authority (PSA). He had said that the average age of a teacher in the primary and secondary level in the Philippines is concentrated on the right tail of the age distribution. This

${ }^{3}$ G.R. No. 211273 dated 18 April 2018. 
means that teachers in grade schools and high schools are, on average, old (PSA, 2013). Our data, has thus highlighted the difference between college professors, and the primary and secondary school teachers.

\section{Results and Discussion}

\subsection{Descriptive Analysis}

This study performed the descriptive analysis so as to analyse the mean and standard deviations of the constructs used. Table 2 illustrates.

Table 2: Descriptive Statistics

\begin{tabular}{lccrr}
\hline Constructs & Mean & Std. Dev. & Min & Max \\
\hline Leadership Styles & & & & \\
Transformational & 4.16 & 0.42 & 2.9 & 4.8 \\
Transactional & 3.01 & 0.37 & 2.42 & 3.75 \\
Laissez-fare & 1.53 & 0.53 & 1 & 2 \\
$\begin{array}{l}\text { University Performance } \\
\text { BLECPA }\end{array}$ & 49.11 & 7.39 & 19.02 & 90.42 \\
\hline
\end{tabular}

From Table 2, it can be seen that transformational leadership is the most common leadership style observed in the educational setting of the Philippines which offer accountancy programmes. In comparison, the laissez-fare leadership style is the least practised. This finding implies that leaders in the educational settings in the Philippines are more inclined towards adopting transformational leadership practices. Thus, it can be inferred that the academics in this country stimulate or activate their subordinates/students by expressing positive emotions and interactions. Although transformational leadership is considered a fairly new concept in emerging countries, this outcome derived from the current study suggests that majority of these academics had been trained overseas and mainly in western countries like Australia, the US or the UK. It is believed that these academics have more opportunities to interact with other individuals, such as the supervisors, course-instructors or programme coordinators, hence, inspiring them to practise transformational leadership. This exposure offers a new perspective which also influenced the Filipino leaders in ways where they too are able to motivate their subordinates and students. This result is in line with previous empirical 
works conducted by Thu et al. (2017), in the Vietnamese educational context. Although the current study found that the transactional leadership is less practised than transformational leadership, there is evidence to suggest that it is also a common practice in the Philippines university setting (Abenes et al., 2017). This phenomenon occurs due to the educational system, the academic leaders and the faculty members who are bounded by the structures and procedures imposed by the country's formal rules and policies. This situation creates the need for the leaders to maintain a consistent standard and to cultivate a constructive relationship with the faculty members and the students. This study shows that even though the academic leaders and the faculty members act as superiors, they still provide support through recommendations instead of directives, unless a violation of norms is evident.

\subsection{Regression Analysis}

\section{(i) Estimation Procedure}

Given the nature of the data we had collected, we also used the crosssectional data estimation for analysis. The general model structure is as follows:

$$
y_{i}=\beta_{0}+\sum_{i=1}^{n} \beta_{i} x_{i}+u_{i}
$$

where $u_{i}$ is the stochastic disturbance term, $y_{i}$ is the dependent variable, $x_{i}$ is the set of $n$ independent regressors, $\beta_{i}^{\prime} \mathrm{s}$ are the slope coefficients of the regressors, and $\beta_{0}$ is the intercept. When all of the assumptions of the CLRM are satisfied, the OLS is the best linear unbiased estimator (BLUE) over all other estimation methods (Gujarati \& Porter, 2009). In our study, however, the dependent variable is bounded (i.e. $y_{i}$ is within the range $[38,69]$ for the McGregor measure) which is clearly a violation of the CLRM assumptions, due to the potential estimate falling outside the identified range.

Making estimations of the discrete choice model with the usual OLS, i.e. linear probability model, is not our best option due to various harmful results, such that the estimated outcome of $y_{i}$ may not be within the observed range of the gathered data (Gujarati \& Porter, 2009; Greene \& Hensher, 2010; Greene, 2011). Because of this, variations to the qualitative response models such as the multinomial logit and the ordered probit techniques were used. These techniques require a more 
advanced estimation procedure, known as the maximum likelihood estimation (MLE) (STATA 12.0). Thus, it was used to assist all our estimation procedures.

The log likelihood function is in the following form:

$$
\ln L=\sum_{i=1}^{n} \ln \int_{-\infty}^{\infty}\left[\prod_{t=1}^{T_{i}} P\left(Y_{i, t}=y_{i, t} \mid x_{i, t}^{\prime} \beta+u_{i}\right] f\left(u_{i}\right) d u_{i}\right.
$$

where $\boldsymbol{P ( . )}$ may be in logit or probit form (Greene, 2011). These loglikelihoods are what we maximised in order to produce estimates for the parameters. Note however, that several studies (Pagano, Panetta, \& Zingales, 1998; Datta, Iskandar-Datta, \& Patel, 2000) had claimed that the more appropriate methodology to be used is the probit model, but the logit model was able to provide the natural logarithm of the estimated odds ratio, which was in the following form:

$$
L=\ln \left(\frac{\operatorname{Prob}\left(y_{i, t}=1\right)}{\operatorname{Prob}\left(y_{i, t}=0\right)}\right)
$$

The difference between the logit and the probit methodology is determined by how these models define $\boldsymbol{P}($.). The logit model uses the cumulative distribution function $(\mathrm{CDF})$ of the logistic distribution while the probit model uses the CDF of the standard normal distribution. Both functions (i.e. $\alpha+\beta x$ ) would take any number, and rescale it to fall between 0 and 1 , through a theoretical model that transforms the function into a probability distribution. Hence, any function can be linked to yield a predicted probability through a "link function". Gujarati and Porter (2009) had however, noted that the choice over the other method is sufficiently arbitrary, so we checked to see if both models produced the same result in terms of the relationship of each regressor to the dependent variables. Gujarati and Porter (2009) further explained that both models yielded similar inferences, so we used both models to check for robustness. It was noted that the resulting coefficients in both the logit and the probit model had to be adjusted in order to produce a sensible analysis. Given the discussion above, we thus arrived at the final estimable models shown below:

$$
\begin{aligned}
\text { LeadershipStyle }_{i}= & \beta_{0}+\beta_{1} \text { Age }_{i}+\beta_{2} \text { Gender }_{i}+\beta_{3} \text { Education }_{i}+ \\
& \beta_{4} \text { Location }_{i}
\end{aligned}
$$

Performance $_{i}=\beta_{0}+\beta_{1}$ LeadershipStyle $_{i}$ 
Equation 4 allows us to determine what demographic factors would affect an academic leader's leadership style. The estimated beta coefficients for the intercept refer to the log odds of an academic administrator having a certain leadership style, given his/her age, gender, educational status, and location. Equation 5 allows us to determine whether the demographic profile of the academic leaders have a significant effect on their leadership style. This intertwined set of equations are reflected in the research framework, wherein the demographic profile affected the academic leadership style while the latter affected the performance.

\section{(ii) Results}

The hypothesis stating that the demographic characteristics of the academic administrators have an effect on their leadership style was accepted. There was statistical evidence to show that age was an important determinant of leadership style. This occurs when following Bass' full range of leadership framework both for the logit and probit regression. We observed that the sign was negative and this implied that the younger administrators leaned toward the transformational style of the leadership spectrum. This outcome is consistent with previous works conducted by Wong et al. (2013), and Oshagbemi and Ocholi (2013). Our current result is expected because younger people tend to be more flexible; they also tend to have more energy to stimulate and inspire other people when compared to their older counterparts. The younger leaders also carry more serious life goals which also impact their awareness of the importance of obtaining awards and promotions, which is not noted in the leaders above the age of 60 . We further found that the location of the academic leader was another strong factor that influenced their leadership style. This finding may be due to the fact that the Philippines' education system is undergoing changes at every level, hence it seems that more people from within and outside Manila are becoming more aware of the relationship between leadership style and faculty and student performance. The findings of this study are consistent with those of previous studies (Mohammed, Othman, \& Silva, 2012; Jones \& Bekhet, 2015; Francis, 2017). We found that gender was associated with transactional leadership, and that transactional leadership was practiced more by female leaders. This outcome thus indicates that within the Philippines' educational setting, female leaders tend to reward their followers, whether subordinates or students, when they have performed as expected. Female leaders also tend to point out errors and shortcomings when followers fail to do as expected. In 
that regard, the hypothesis stating that academic administrators and faculty members' leadership style has an effect on student performance is supported. In discussing the impact of the three types of leadership styles on students' performance, this study found that academic leaders who displayed characteristics that were reminiscent of the three types of leadership styles also seemed to have a positive relationship with students' performance. This shows that the students' performance is equally affected by the three leadership styles. Thus, it is inferred that students' performance is affected by leaders who not only emphasise on policies, rules, human needs, political and shared vision and values, but also leaders who inspire and direct them. Our findings hence conform to those of Bolman and Deal (2017) who had indicated that the leadership style of administrators had positively affected school performance. Leithwood et al. (2004) also validated the findings of this study as seen by the fact that more obligations rested on the principals to display higher instructional leadership characteristics. This can be accomplished through proper and strategic interventions which are aimed at effective teaching and learning, thereby creating a positive reinforcement towards the academic performance of the students.

While it appears that the students' performance had been influenced by the types of leadership styles, we also found strong evidence which implied school performance had also been enhanced by leaders from the transformational spectrum. This finding is not surprising, since transformational leadership tend to include inspirational motivation, intellectual stimulation and individualised consideration, all of which are aimed at empowering the campus communities towards thinking critically and creatively. This phenomenon also encourages the campus communities to be critical towards self, work and the academic institution, at large. For this to occur, a supportive environment that promotes the articulation of thoughts, feelings and experiences is vital. In the context of the educational setting, followers seemed to prefer that leaders have the characteristics of friendship, collaboration and collegiality, particularly leaders who are humble, honest, credible, respected and able to mentor. This seems to prevail in the current study which involves the Philippines, whose culture is that of the collectivistic norm. Because of this, it is possible that the outcome may be different for the business setting, where leaders are selected based on specific competencies (Guerrero, Teng-Calleja, \& Hechanova, 2018).

From the demographic profiles, our regression results reveal that only age is negatively and significantly related to academic performance 
Impact of Leadership Style and Demographic Profile on Accounting Student Performance

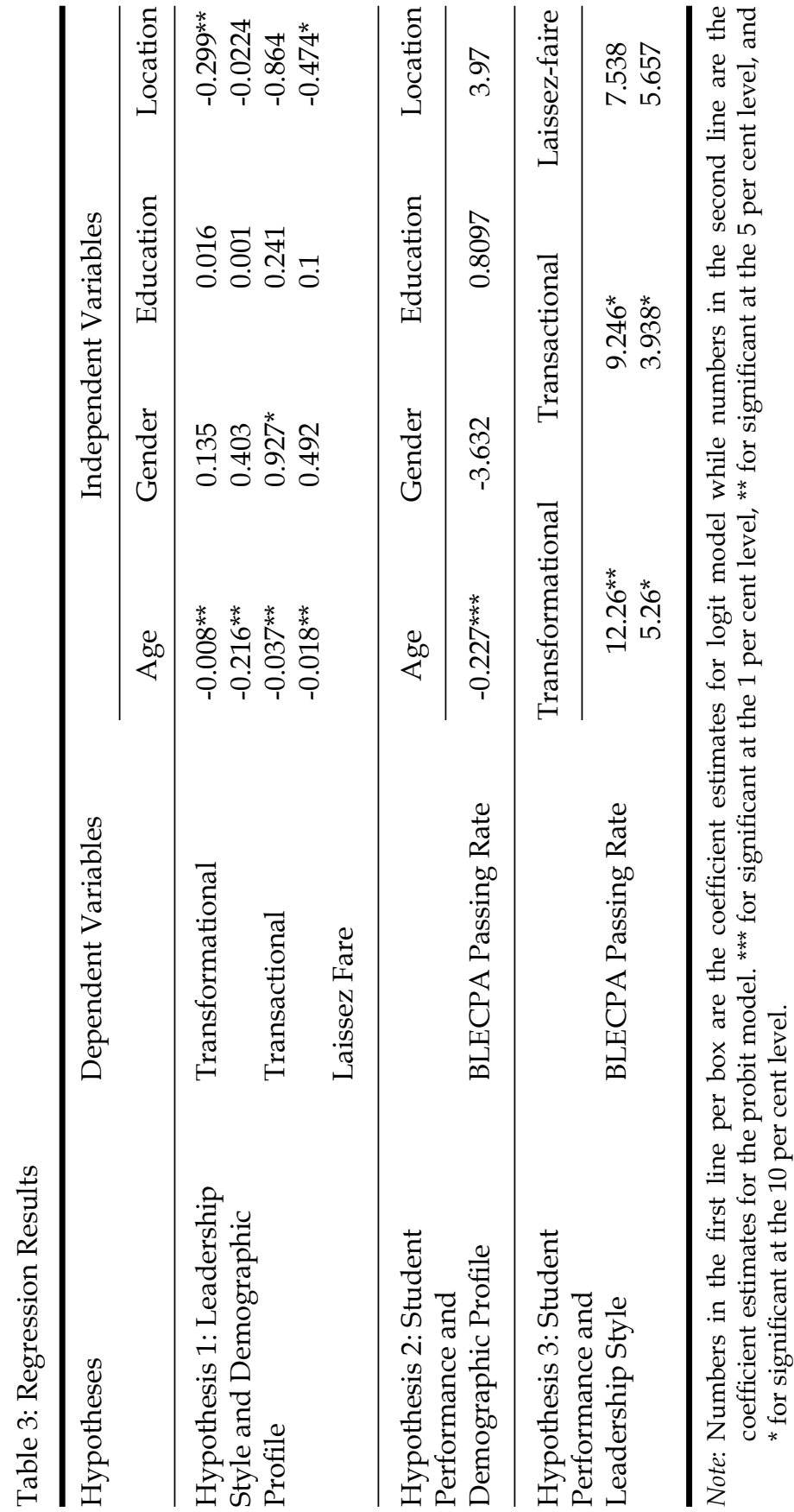


$(\mathrm{p}<0.01)$. This means that the younger the age of the administrator, the higher the probability of passing the BLECPA. Here, it had increased by 22 per cent. This finding conforms to literature (Nasir, 2012) which had confirmed that there was a significant relationship between the demographic profiles of academic leaders and students' academic achievements. Younger professors and faculty members are perceived more positively by students when compared to older academic leaders. The reason is because the former are more relatable, more dynamic and more energetic. We believe that this outcome could be due to the fact that the academic administrators and faculty members of the Philippines, at the time of this study, were younger in age. This finding is thus, another research area to be investigated for future studies since the age factor may change over time.

\section{Implications and Conclusions}

This study has attempted to examine how the demographic profiles of the academic leaders influence their leadership styles, hence the students' academic performance, in the context of 19 of the Philippines top performing business institutions located in Luzon Island. As mentioned earlier, this study offers three valuable contributions. Undoubtedly, different leadership styles promote different developments, and this is even more distinct between academia and the business world. There is no one-size fits all kind of approach simply because different organisations including country contexts, have different cultural values.

In terms of academic contribution, this study appears to be one of the first attempt to understand the impact of demographic profiles, and academic leadership style on students' academic performance. This study incorporated both the academic administrators, and faculty members' perspectives, hence, it adds to the existing literature on leadership styles. In addition, this study also engages a more robust technique for analysis, the logit and probit models, which are found to control the possible errors better than the linear regression model.

This study provides evidence to suggest that no singular style of leadership is best suited for academic institutions even when the agenda is to enhance the quality of the accounting education. Overall, the findings of this study have shown that students' academic performance are derived from the various dimensions of the leadership style, hence, it is deduced that for organisations such as universities to attain the 
goals they have established, the leaders who are also the academic administrators and the faculty members, need to be, first and foremost, exposed to the different leadership styles. The leaders also need to be willing to apply the most appropriate leadership style that is contingent to the situation at hand. While all the three leadership styles are found to be important in harnessing the students' academic performance, it is also safe to assert that there are differences in the strength of the leadership styles which can create different impact on academic performance. Our findings suggest that the students' performance can be enhanced further through the support of the academic administrator and the faculty members who have high levels of energy, strong beliefs in their followers or students, and are ready to stimulate their followers' creativity and intrinsic motivation. Under such types of leadership, a trustworthy relationship between the leaders and the followers can be built. This is expected to encourage a free flow of new ideas. Faculty members who also serve as transformational leaders may help to accelerate the students' engagement with the subject taught. Under transformational leadership, students are given more freedom in their own learning, thus they were more likely to retain their knowledge and immerse themselves in the course contents. This would make them better at assimilating ideas and developing their critical thinking skills. In this regard, it is not surprising that students would be able to perform well. Based on the findings of this study, it is recommended that the faculty members/course instructors promote transformational classroom leadership to enhance learning and creativity.

The students' class participation also needs to be emphasised. Through an open climate of learning, classrooms can be transformed into a learning ground where the students are academically engaged, personally know their course instructors, and they also feel safe and secure in exchanging ideas. Such an environment is supportive and nonthreatening.

The proper interpretation of this study can be used to develop a better set of university regulations. Policy makers can formulate rules and regulations based on the findings of this paper where the need is to make the learning ground as conducive as ever for universities in the Philippines offering accountancy education. This is crucial if the graduates' employability is of concern. The accountancy education has been described as one that is very demanding and stringent. Since there has been reports highlighting the poor passing rates in the BLECPA examinations, it is opportune that academics, practitioners, curriculum 
designers, policy makers and university administrators take the quality of the accountancy education into consideration. Evidently, one of the ways to resolve this issue is to invest in academic leaders who have the qualities mentioned in the findings above. Doing so can increase the supply of the CPA's in the region. This issue can also alert other ASEAN countries towards addressing the inadequacies affecting the ASEAN region, currently.

The results of this study informed universities that leadership style and their demographic profiles are indeed related and relevant when assessing school performance. Universities should incorporate the outcome derived from this study when formulating regulations and grooming academic leaders. Many measures of today's leadership are concurrent with the ones found in the current study. For the purpose of selecting the right leaders in support of the academic campus, the respective universities can formulate their own set of questionnaires, such as the one used in the current study as a means to evaluate the characteristics and profiles of their targeted subjects.

Our study is possibly an innovative step taken to narrow the research gap between academic leadership and academic performance. In line with the specific interest that we have taken, it is proposed that future research focus on non-academic administrators to see how their performance affect the institutions. Our findings have shown the importance of the differences of the localities of institutions (i.e. urban vs. rural) offering the accountancy programmes, among other demographic characteristics that controlled the leadership style of the administrators. With this in mind, we propose that this study be extended to the Visayas and Mindanao regions as well. In this study, we further deduce that more relevant considerations should be made for identifying the determinants of the university students' performance in the context of the Philippines. Other factors not yet included comprise: student aptitude, curriculum and the ratings of the universities by agencies. In addition, it is common knowledge that in the Philippines, only a handful of review centres and universities have been successful in maintaining consistent and satisfactory BLECPA results. Most of the institutions used in the current study were established ones (Professional Regulation Commission, 2017), hence future studies may consider using the not so well-established universities for comparison. This can add to the current findings so that more can be done to make the accountancy education in the Philippines more competitive globally. 


\section{References}

Abenes, C., Corpus, C., \& Oblea, M. (2017). The effect of leadership style and demographic profile on BSA student performance and faculty effectiveness in Metro Manila (Doctoral thesis, De La Salle University Manila).

Ahumada, C.J. (2016). Comprehension of counselor education course materials in online versus face-to-face courses (Doctoral thesis, Winona State University). Retrieved from https://openriver.winona.edu/counseloreducationcap stones/46/

Amin, S., \& Kamal, Y. (2016). Impact of natural born leader qualities on the project team performance: The influences of demographics (gender and age). International Journal of Management, Accounting and Economics, 3(5), 306-318.

Asrar-ul-Haq, M., \& Kuchinke, K.P. (2016). Impact of leadership styles on employees' attitude towards their leader and performance: Empirical evidence from Pakistani banks. Future Business Journal, 2(1), 54-64. http:// dx.doi.org/10.1016/j.fbj.2016.05.002

Avolio, B., \& Bass, B. (2004). Multifactor leadership questionnaire. Redwood City, CA: Mind Garden.

Balwant, P.T., Birdi, K., Stephan, U., \& Topakas, A. (2018). Transformational instructor-leadership and academic performance: A moderated mediation model of student engagement and structural distance. Journal of Further and Higher Education, 43(7), 884-900. http://dx.doi.org/10.1080/030987 7X.2017.1420149

Barbuto, J.E., \& Burbach, M.E. (2006). The emotional intelligence of transformational leaders: A field study of elected officers. The Journal of Social Psychology, 146(1), 51-64. http://dx.doi.org/10.3200/SOCP.146.1.51-64

Baron, P., \& Corbin, L. (2012). Student engagement: Rhetoric and reality. Higher Education Research \& Development, 31(6), 759-772. http://dx.doi.org/10. 1080/07294360.2012.655711

Bass, B.M. (1985). Leadership: Good, better, best. Organizational Dynamics, 13(3), 26-40. http://dx.doi.org/10.1016/0090-2616(85)90028-2

Bass, B.M. (1990). From transactional to transformational leadership: Learning to share the vision. Organizational Dynamics, 18(3), 19-31. http://dx.doi. org/10.1016/0090-2616(90)90061-S

Bass, B.M., \& Avolio, B.J. (1994). Transformational leadership and organizational culture. The International Journal of Public Administration, 17(3-4), 541-554. http://dx.doi.org/10.1080/01900699408524907

Bell, C., Rvanniekerk, R., \& Nel, P. (2015). The relationship between some demographic variables and leadership effectiveness among local government managers in South Africa. African Journal of Business Management, 9(2), 50-58. http://dx.doi.org/10.5897/ AJBM2013.7299

Bolman, L.G., \& Deal, T.E. (2017). Reframing organizations: Artistry, choice and leadership. San Francisco, CA: John Wiley \& Sons. 
Bonetta, L. (2011). Moving up the academic ladder. AAAS. Retrieved from https:/ / www.sciencemag.org/features/2011/02/moving-academic-ladder

Bronkhorst, B., Steijn, B., \& Vermeeren, B. (2015). Transformational leadership, goal setting, and work motivation: The case of a Dutch municipality. Review of Public Personnel Administration, 35(2), 124-145. http://dx.doi. org/10.1177/0734371X13515486

Commission on Higher Education. (2011). CHED memorandum order no. 2 series of 2011. Retrieved from http://www.ched.gov.ph/wp-content/uploads/ 2013/07/CMO-02-s2011.pdf

Datta, S., Iskandar-Datta, M., \& Patel, A. (2000). Some evidence on the uniqueness of initial public debt offerings. Journal of Finance, 55(2), 715-743. http:/ /dx.doi.org/10.1111/0022-1082.00224

Day, C., Gu, Q., \& Sammons, P. (2016). The impact of leadership on student outcomes: How successful school leaders use transformational and instructional strategies to make a difference. Educational Administration Quarterly, 52(2), 221-258. http:/ / dx.doi.org/10.1177/0013161X15616863

Dyck, B., \& Neubert, M.J. (2009). Principles of management. Mason, OH: SouthWestern Cengage Learning.

Eagly, A.H., \& Carli, L.L. (2003). The female leadership advantage: An evaluation of the evidence. The Leadership Quarterly, 14(6), 807-834. http://dx.doi. org/10.1016/j.leaqua.2003.09.004

Epitropaki, O., \& Martin, R. (2013). Transformational-transactional leadership and upward influence: The role of relative leader-member exchanges (RLMX) and perceived organizational support (POS). The Leadership Quarterly, 24(2), 299-315. http://dx/doi.org/10.1016/j.leaqua.2012.11.007

Francis, U.C. (2017). Influence of selected psycho-demographic variables on leadership styles among leaders of administrative ministries in Lagos, Nigeria. African Journal for the Psychological Studies of Social Issues, 20(1), 15-27.

Greene, W.H. (2011). Econometric analysis (7th ed.). Upper Saddle River, NJ: Pearson Education, Inc.

Greene, W.H., \& Hensher, D.A. (2010). Modeling ordered choices: A primer. Cambridge, UK: Cambridge University Press.

Guerrero, J.M., Teng-Calleja, M., \& Hechanova, M.R.M. (2018). Implicit change leadership schemas, perceived effective change management, and teachers' commitment to change in secondary schools in the Philippines. Asia Pacific Education Review, 19(3), 375-387. http://dx.doi.org/10.1007/s12564-0189545-6

Gujarati, D.N., \& Porter, D.C. (2009). Basic econometrics. New York, NY: McGraw-Hill.

Huguet, B.C.S. (2017). Effective leadership can positively impact school performance. On the Horizon, 25(2), 96-102. http://dx.doi.org/10.1108/ OTH-07-2016-0044

Jeffrey, C. (2015). Research on professional responsibility and ethics in accounting. Bingley, UK: Emerald Publications. 
Jones, S.K., \& Bekhet, K.E. (2015). Leadership styles and personal demographic profile: An empirical study on private business organizations in Egypt. International Journal of Sciences: Basic and Applied Research, 20(2), 127-147.

Judge, T.A., \& Piccolo, R.F. (2004). Transformational and transactional leadership: A meta-analytic test of their relative validity. Journal of Applied Psychology, 89(5), 755-768. http:/ / dx.doi.org/10.1037/0021-9010.89.5.755

Karadağ, E., Bektaş, F., Çoğaltay, N., \& Yalçin, M. (2015). The effect of educational leadership on students' achievement: A meta-analysis study. Asia Pacific Education Review, 16(1), 79-93. http://dx.doi.org/10.1007/s12564015-9357-x

Kim, S., \& Yoon, G. (2015). An innovation-driven culture in local government: Do senior manager's transformational leadership and the climate for creativity matter? Public Personnel Management, 44(2), 147-168. http:// dx.doi.org/10.1177/0091026014568896

Koh, W.L., Steers, R.M., \& Terborg, J.R. (1995). The effects of transformational leadership on teacher attitudes and student performance in Singapore. Journal of Organizational Behavior, 16(4), 319-333. http://dx.doi.org/ 10.1002/job.4030160404

Kythreotis, A., Pashiardis, P., \& Kyriakides, L. (2010). The influence of school leadership styles and culture on students' achievement in Cyprus primary schools. Journal of Educational Administration, 48(2), 218-240. http://dx.doi. org/10.1108/09578231011027860

Leithwood, K., Louis, K.S., Anderson, S., \& Wahlstrom, K. (2004). Review of Research: How leadership influences student learning. New York: University of Minnesota, Center for Applied Research and Educational Improvement.

LePine, M.A., Zhang, Y., Crawford, E.R., \& Rich, B.L. (2016). Turning their pain to gain: Charismatic leader influence on follower stress appraisal and job performance. Academy of Management Journal, 59(3), 1036-1059. http:// dx.doi.org/10.5465/amj.2013.0778

MacNeil, A.J., Prater, D.L., \& Busch, S. (2009). The effects of school culture and climate on student achievement. International Journal of Leadership in Education, 12(1), 73-84. http:/ / dx.doi.org/10.1080/13603120701576241

McGregor, D. (1960). Theory X and theory Y. In D. Pugh (Eds.), Organization Theory (pp 358-374), London, UK: Penguin Books.

Mohammed, K.A., Othman, J., \& Silva, J.L.D. (2012). Social demographic factors that influence transformational leadership styles among top management in selected organizations in Malaysia. Asian Social Science, 8(13), 51-58. http:/ / dx.doi.org/10.5539/ass.v8n13p51

Nasir, M. (2012). Demographic characteristics as correlates of academic achievement of university students. Academic Research International, 2(2), 400-405.

Ndlovu, M. (2009). An analysis of teacher competencies in a problem-centred approach to dynamic geometry teaching (Doctoral thesis, University of South Africa).

Newland, A., Newton, M., Podlog, L., Legg, W.E., \& Tanner, P. (2015). Exploring the nature of transformational leadership in sports: A phenomenological 
examination with female athletes. Qualitative Research in Sport, Exercise and Health, 7(5), 663-687. http://dx.doi.org/10.1080/2159676X.2015.1007889

Okoji, O.O. (2015). Relationship between school principals' leadership styles and teachers' job performance in Ondo State, Nigeria. IFE Psychology: An International Journal, 23(2), 133-138.

Oshagbemi, T., \& Ocholi, S.A. (2013). Influences on leadership behaviour: A binomial logit model. International Journal of Social Economics, 40(2), 102-115. http:/ / dx.doi.org/10.1108/03068291311283580

Oxford Economics. (2012). Hays global skills index. Retrieved from http:/ /www. oxfordeconomics.com/Media/Default/economic-impact/my-oxford/Hays_ Index_2012.pdf

Pagano, M., Panetta, F., \& Zingales, L. (1998). Why do companies go public? An empirical analysis. Journal of Finance, 53(1), 27-64. http://dx.doi.org/ 10.1111/0022-1082.25448

Podsakoff, P.M., MacKenzie, S.B., Lee, J.Y., \& Podsakoff, N.P. (2003). Common method biases in behavioral research: A critical review of the literature and recommended remedies. Journal of Applied Psychology, 88(5), 879-903. http:/ / dx.doi.org/10.1037/0021-9010.88.5.879

Professional Regulatory Commission. (2017). October 2017 CPA board exam result summary. Retrieved from http://www.prcboard.com/2017/10/List-ofPassers-October-2017-CPA-Board-Exam-Results.html

Robinson, V.M., Lloyd, C.A., \& Rowe, K.J. (2008). The impact of leadership on student outcomes: An analysis of the differential effects of leadership types. Educational Administration Quarterly, 44(5), 635-674. http://dx.doi. org/10.1177/0013161X08321509

Ryan, J.C., \& Tipu, S.A. (2013). Leadership effects on innovation propensity: A two-factor full range leadership model. Journal of Business Research, 66(10), 2116-2129. http://dx.doi.org/10.1016/j.jbusres.2013.02.038

Saeed, R., Hashmi, A., Lodhi, R.N., Ahmad, M., Arshad, H.M., \& Ahmad, M.A. (2013). The effect of transformational leadership on organisational commitment with a mediating effect of psychological empowerment. Journal of Basic and Applied Scientific Research, 3(6), 28-36.

Santos, T. (2008). Higher education plagued by endemic poor board results. The Varsitarian. Retrieved from http://varsitarian.net/news/20080907/higher_ education_plagued_by_endemic_poor_bo

Sawati, M.J., Anwar, S., \& Majoka, M.I. (2013). Do qualification, experience and age matter for principals leadership styles? International Journal of Academic Research in Business and Social Sciences, 3(7), 403-413. http://dx.doi.org/ 10.6007/IJARBSS/v3-i7/63

Sirisookslip, S., Ariratana, W., \& Tang, K.N. (2015). The impact of leadership styles of school administrators on affecting teacher effectiveness. Procedia Social and Behavioral Sciences, 186(May), 1031-1037. http://dx.doi.org/ 10.1016/j.sbspro.2015.04.022 
Summers, J.J., Waigandt, A., \& Whittaker, T.A. (2005). A comparison of student achievement and satisfaction in an online versus a traditional face-to-face statistics class. Innovative Higher Education, 29(3), 233-250. http://dx.doi. org/ 10.1007/s10755-005-1938-x

Tan-Torres, J. (2017). New topics in the CPA board examinations - PRC board of accountancy. Retrieved from https://boa.com.ph/wpcontent/uploads/2017/ 09/09042017-debit-credit-Sept-4-2017-New-CPA-exam-topics-JLT-.pdf

Thu, P.D.X., Pillay, H., \& Mergler, A. (2017). Leadership styles of Vietnamese higher education leaders: Transformational, trans-actional, or laissezfaire. Chan Tho University Journal of Science, 7, 126-137. http://dx.doi. org/10.22144/ctu.jen.2017.058

Van Deventer, K.J. (2007). A paradigm shift in life orientation: A review. South African Journal for Research in Sport, Physical Education and Recreation, 29(2), 131-146. http://dx.doi.org/10.4314/sajrs.v29i2.25975

Wong, C.A., Cummings, G.G., \& Ducharme, L. (2013). The relationship between nursing leadership and patient outcomes: A systematic review update. Journal of Nursing Management, 21(5), 709-724. http://dx.doi.org/10.1111/ jonm.12116

World Bank Group. (2014). Current status of the accounting and the auditing profession in the ASEAN countries. Retrieved from http:/ / www.aseanaccountants. org/files/afa_report-printed_version.pdf

Yahya, S.A. (2015). Leadership styles, types and students' academic achievement in Nigeria (Doctoral thesis, Universiti Tun Hussein Onn Malaysia). 
John C. Cha, James T. Calleja, Patrick G. Mendoza, Jose L. Yupangco and Rodiel C. Ferrer

\section{Appendices}

\section{Appendix 1}

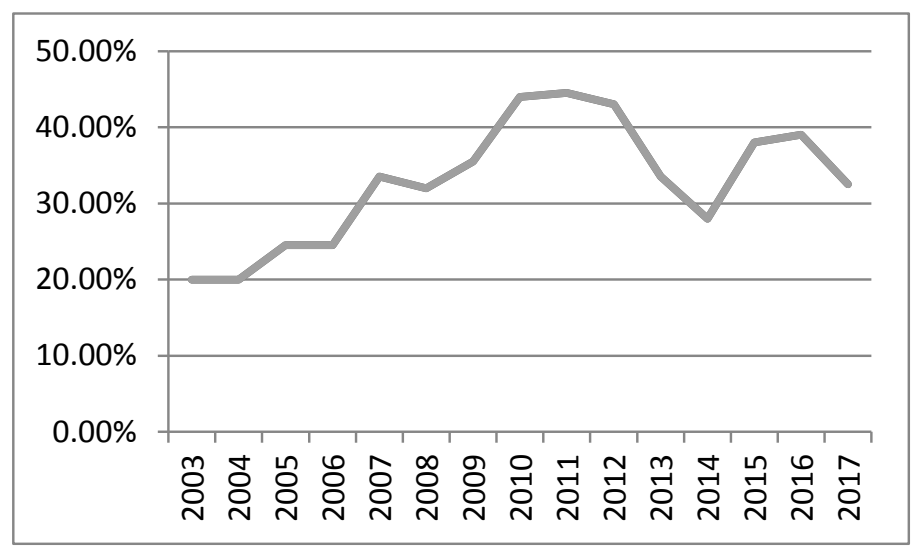

Figure 1: National BLECPA Passing Rates (2003-2017)

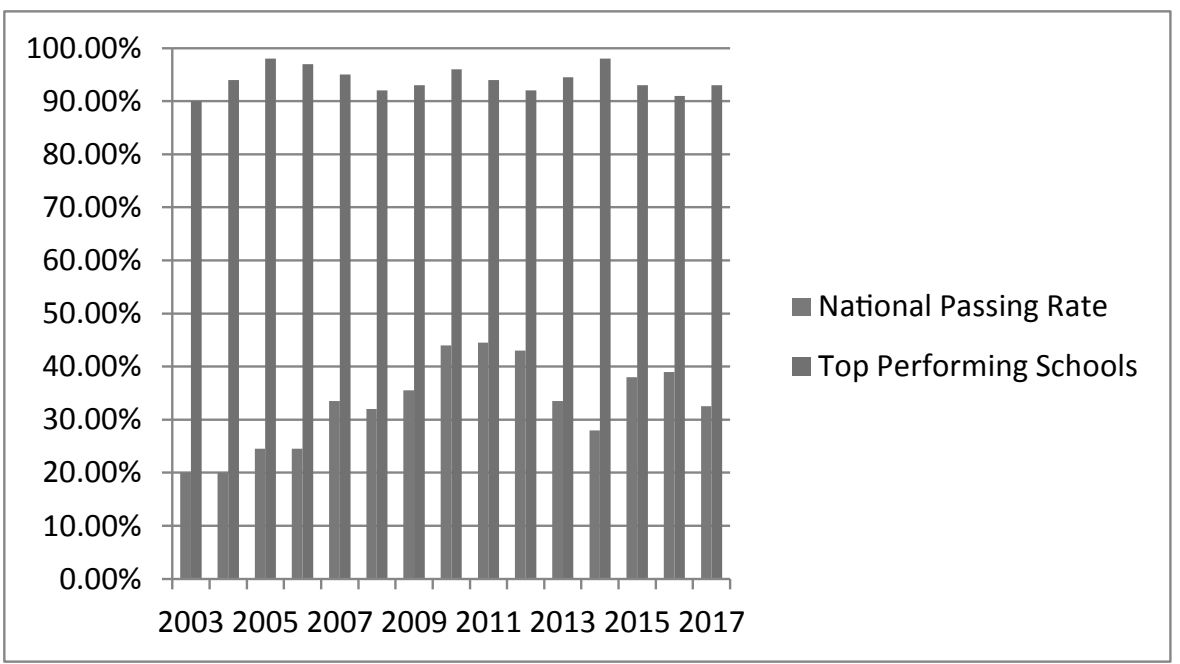

Figure 2: Top Performing Universities and National Passing Rate in BLECPA 


\section{Appendix 2}

\section{Survey Questionnaire}

\section{Information}

Gender:

Age:

Marital Status:

Number of Dependents:

Primary Place of Residence:

Highest Degree of education completed? If currently enrolled, highest degree received.

- $\quad$ Associate degree (e.g. AA, AS)

- $\quad$ Bachelor's degree (e.g. BA, BS)

- $\quad$ Master's degree (e.g. MA, MS, MEd)

- $\quad$ Professional degree (e.g. MD, DDS, DVM)

- $\quad$ Doctorate (e.g. PhD, EdD)

Monthly (net) compensation income (Choose range):

- Less than P10,000

- $\mathrm{P} 10,000$ - P19,999

- $\mathrm{P} 20,000-\mathrm{P} 24,999$

- $\mathrm{P} 25,000-\mathrm{P} 29,999$

- $\mathrm{P} 30,000-\mathrm{P} 39,999$

- $\mathrm{P} 40,000-\mathrm{P} 49,999$

- $\mathrm{P} 50,000$ - P59,999

- $\mathrm{P} 60,000$ - $\mathrm{P} 69,999$

- $\mathrm{P} 70,000$ - $\mathrm{P} 79,999$

- $\quad \mathrm{P} 80,000-\mathrm{P} 89,999$

- $\mathrm{P} 90,000$ - $\mathrm{P} 99,999$

- More than P100,000

\section{Academic Rank}

- Professional Emeritus

- Full time Professor

- Associate Professor

- Instructor Assistant Instructor

- Lecturer

- Guest Lecturer 
Please rate the statements from $1=$ Not at all, 2=Once in a while, $3=$ Sometimes, $4=$ Fairly Often, $5=$ Always

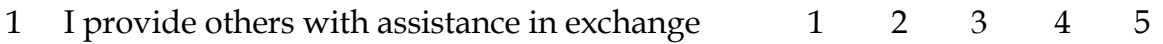
for their efforts.

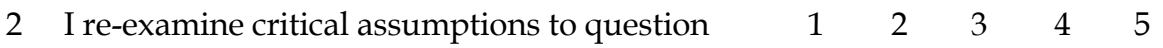
whether they are appropriate.

$\begin{array}{lllllll}3 & \text { I fail to interfere until problems become serious. } & 1 & 2 & 3 & 4 & 5\end{array}$

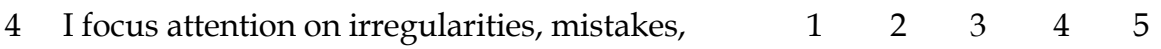
exceptions, and deviations from standards.

5 I avoid getting involved when important issues arise.

6 I talk about my most important values and beliefs.

7 I am absent when needed.

8 I seek differing perspectives when solving problems.

9 I talk optimistically about the future.

10 I instill pride in others for being associated with me.

11 I discuss in specific terms who is responsible for achieving performance targets.

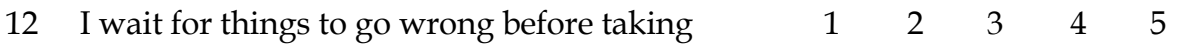
action.

13 I talk enthusiastically about what needs to be $\begin{array}{lllllll}1 & 2 & 3 & 4 & 5\end{array}$ accomplished.

14 I specify the importance of having a strong $\quad \begin{array}{llllll}1 & 2 & 3 & 4 & 5\end{array}$ sense of purpose.

15 I spend time teaching and coaching. $\quad \begin{array}{llllll}1 & 2 & 3 & 4 & 5\end{array}$

16 I make clear what one can expect to receive $\quad \begin{array}{llllll}1 & 2 & 3 & 4 & 5\end{array}$ when performance goals are achieved.

17 I show that I am a firm believer in $\quad \begin{array}{llllll}1 & 2 & 3 & 4 & 5\end{array}$ "If it ain't broke, don't fix it."

18 I go beyond self-interest for the good of $\quad \begin{array}{llllll}1 & 2 & 3 & 4 & 5\end{array}$ the group.

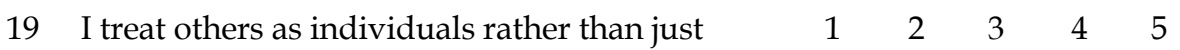
as members of the group.

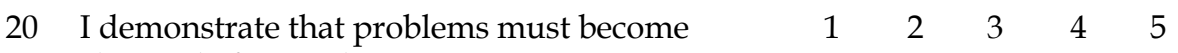
chronic before I take action. 
21 I act in ways that build others' respect for me.

22 I concentrate my full attention on dealing with mistakes, complaints, and failures.

23 I consider the moral and ethical consequences of decisions.

24 I keep track of all mistakes.

25 I display a sense of power and confidence.

26 I articulate a compelling vision of the future.

$\begin{array}{lllll}1 & 2 & 3 & 4 & 5\end{array}$

27 I direct my attention toward failures to meet standards.

28 I avoid making decisions.

29 I consider each individual as having different needs, abilities, and aspirations from others.

30 I get others to look at problems from many different angles.

31 I help others to develop their strengths.

32 I suggest new ways of looking at how to complete assignments.

33 I delay responding to urgent questions.

34 I emphasize the importance of having a collective sense of mission.

35 I express satisfaction when others meet expectations.

36 I express confidence that goals will be achieved.

37 I am effective in meeting others' job-related needs.

$\begin{array}{llllllll}38 & \text { I use methods of leadership that are satisfying. } & 1 & 2 & 3 & 4 & 5\end{array}$

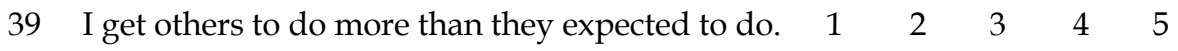

$\begin{array}{llllllll}40 & \text { I am effective in representing my group to } & & 1 & 2 & 3 & 4 & 5\end{array}$ higher authority.

$\begin{array}{llllllll}41 & \text { I work with others in a satisfactory way. } & & 1 & 2 & 3 & 4 & 5\end{array}$

42 I heighten others' desire to succeed. $\quad \begin{array}{llllll}1 & 2 & 3 & 4 & 5\end{array}$

$\begin{array}{llllllll}43 & \text { I am effective in meeting organizational } & & 1 & 2 & 3 & 4 & 5\end{array}$ requirements.

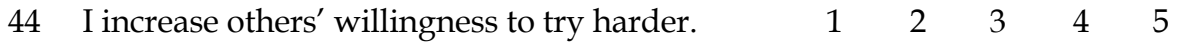

$\begin{array}{llllllll}45 & \text { I lead a group that is effective. } & 1 & 2 & 3 & 4 & 5\end{array}$ 
